\title{
Failure To Thrive In Children Under Two Years Of Age And Associated Factors, A Hospital- Based Study \\ Hassan M Khalil (DCH) ${ }^{1}$, Sundus M Husain ( FICMS $)^{2}$, Maghreb S Alkhateeb $(\mathrm{DCH})^{3}$ and Jalil I Alezzi (FICMS) ${ }^{4}$ \\ Abstract
}

Background: Failure to thrive is a common problem in infancy and children result from inadequate nutrition or chronic illnesses.

Objective: To assess the severity and risk factors associated with failure to thrive.

Patients and Methods: In this cross-section study, 50 children under 2 years of age with FTT admitted to Jalawla general hospital, Diyala province, Iraq during the period 1st of Jan. to 1st of July 2018 were studied. The parameters used to assess the growth of involved children included weight, height and head circumference for ages, using Z-score (Standard deviation score) and the mean had been taken from Tanner growth chart. Other child variables included socioeconomic status and hemoglobin level also studied.

Results: The male: female ratio was 1.5:1 and 38 children (76\%) were below one year of age, 25 of them $(50 \%)$ were of low socioeconomic state and the majority from overcrowded families. Maternal illiteracy was recorded in $26(52 \%)$. Twenty-three children $(46 \%)$ were exclusively bottle-fed. Twenty-two children (44\%) their weights for age were < -3SD below the mean, twelve children (14\%) their heights for age were <-3SD, seven children (14\%), had head circumference <-3SD which indicate very severe malnutrition. Most of children in this study were from large size families with low socioeconomic status.

Conclusion: Failure to thrive is a common problem in our locality. Those below one year of age constitutes $76 \%$, and $50 \%$ were from low socioeconomic families.

Keywords: children, failure to thrive, socioeconomic.

Corresponding Author: mousah526@gmail.com

Received: $3^{\text {th }}$ July 2019

Accepted: $18^{\text {th }}$ July 2019

DOI:https://doi.org/10.26505/DJM.17024770703

\section{Introduction}

${ }^{1}$ Jalawla General Hospital- Diyala - Iraq.

${ }^{2}$ Khanaquin General Hospital- Diyala-Iraq.

${ }^{3}$ AlBatool Teaching Hospital- Diyala-Iraq.

${ }^{4}$ College of Medicine- Diyala University -Diyala- Iraq.

The epidemiological outline of infants failing to thrive is indistinct; the linear growth and head circumference may be affected in severe cases [1,2]. The underlying cause of poor weight gain is always inadequate serviceable nourishmen [2,3]. 
Decreased weight gain which results in severe undernourishment can cause unrelenting short stature, secondary immune deficit, and everlasting brain damage [2,4-6]. Decreased weight gain occurs when weight is less than the 2 nd centile for age and gender when plotted on a suitable growth chart and reduced velocity of weight gain that is irregular to growth in length [7-9]. Weight less than 2 nd centile is nearby equivalent to a Z-score of -2; the Z-score is a value that signifies the number of standard deviations from the mean value. Failure to thrive (FTT) occurs in roughly 5 to $10 \%$ of children in primary care settings and 3 to $5 \%$ of those in the referral setting [10.-13]. Risk factors for FFT include prematurity, developmental disruption, congenital anomalies, intrauterine exposure (eg, anticonvulsants, alcohol, and infection), lead poisoning, anemia, and any medical event [14-19]. Psychosocial risk factors for FTT include poverty, certain health and nutrition sights (eg, fear of obesity or cardiovascular disorder, prolonged partial breastfeeding [2,4,14,20-.25.]. FTT is caused by inadequate nutrition secondary to deficient nutrient ingesting, reduced nutrient absorption, amplified urinary or intestinal losses, augmented nutrient needs, or unsuccessful metabolic use $[2,15,17,19,26$ 28].Medical, dietetic, developmental/behavioral, and psychosocial impacts may all affect nutritive status of the child $[13,16,22,25,29,30]$.The majority of cases in primary care setting are secondary to inadequate nutritional consumption [12.14.16,21,24,28]. FTT has traditionally been branded as "organic" or "nonorganic." However, this division has imperfect utility because multiple factors, organic and nonorganic, may interconnect to contribute to FTT in a solitary patient $[13,18,20,22,31]$. Our aims of the study, to find out the prevalence and the severity of FTT in admitted children to Jalawla general hospital as well as studying the associated risk factors .

\section{Patients and Methods}

This descriptive, cross sectional study was conducted on children admitted to Jalawla general hospital, Diyala province, Iraq during period from 1st of Jan. to 1st of July 2018. Fifty children below two years of age with malnutrition and weight below 3rd percentile who admitted to this hospital were included in this study. Full history was taken for each patient from their caretakers, mostly mothers with details regarding age, gender, residence, suffering and duration, presentation on admission, previous illnesses, number of siblings, parent's education, socioeconomic status regarding family income and father's occupation and crowding index (crowding index $=$ No. of persons / No. of rooms). Full clinical examination for the nutritional assessment including pallor, wasting, edema and measurement of growth parameters including weight, height and head circumference by using growth and developmental chart (prepared by J.M. Tanner and R.H.whitehouse) .Weight, height and head circumference were plotted on $\mathrm{Z}$ scores ( standard deviation scores ) (SD). Zscore or SD score= observed value-median 
reference value/SD. of reference population. Poor nutrition is defined as scoring minus two standard deviation or less in weight for age and height for age. Children less than (-3 Z-score ) represent severe malnutrition ,while those of $2 \mathrm{SD}$ and less below the median considered normal.

\section{Ethical consent}

The study protocol and the questionnaires were conducted according to principles of the Declaration of Helsinki, as well as reviewed and approved by the Ethical Research Committee of College of medicine, University of Diyala. Verbal consents were also taken from the parents and caregivers of children involved in the study.

\section{Statistical analysis}

The data were processed and analyzed using the Statistical Package for Social Sciences version 21 (SPSS Inc., Chicago, IL, USA. The results were expressed using percentage and frequencies . A p-value $<0.05$ was considered significant, and the confidence interval was set at $95 \%$.

\section{Results}

Table (1) showed the sociodemographic characteristics of fifty children studied with FTT. Male to female ratio was 1.5:1 and $48 \%$ were aged below 6 months. The majority of children were from Jalawla Town. The illiterate mothers constitute $52 \%$ of affected children. The crowding index was $60 \%$ among families with $\geq 3-5$ members. Table 2 showed the characteristics of weight, Height, and Head circumference of fifty infants with FTT, where the majority of studied infants their weights ,heights and head circumferences were 2-3SD below the mean .Regarding hemoglobin( $\mathrm{Hb})$ level of studied infants with FTT , 76\% of them had Hb level below $11 \mathrm{gm} / \mathrm{dL}$ and only 4 ( $8 \%$ ) infants had $\mathrm{Hb}$ level $<6 \mathrm{gm} / \mathrm{dL}$, while 8 the nonorganic causes constitute $40 \%$ of affected infants. 
Table (1): Sociodemographic characteristics of children with FTT

\begin{tabular}{|c|c|c|c|c|c|}
\hline \multicolumn{3}{|c|}{ Child Variables } & $\begin{array}{l}\text { No. of } \\
\text { children }\end{array}$ & Percent \% & P Value \\
\hline \multirow[t]{2}{*}{ Gender } & \multicolumn{2}{|l|}{ Male } & 30 & $(60 \%)$ & \multirow{2}{*}{0.157} \\
\hline & \multicolumn{2}{|l|}{ Female } & 20 & $(40 \%)$ & \\
\hline & \multicolumn{2}{|l|}{ Total } & 50 & $100 \%$ & \\
\hline \multirow[t]{13}{*}{ Age ( Months) } & \multicolumn{2}{|l|}{$\leq 6$} & \multirow{3}{*}{24} & \multirow{3}{*}{$(48 \%)$} & \multirow[t]{12}{*}{0.000} \\
\hline & male & female & & & \\
\hline & 14 & 10 & & & \\
\hline & $7-12$ & & \multirow{3}{*}{14} & \multirow{3}{*}{$(28 \%)$} & \\
\hline & male & female & & & \\
\hline & 9 & 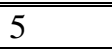 & & & \\
\hline & \multicolumn{2}{|l|}{$13-18$} & \multirow{3}{*}{10} & \multirow{3}{*}{$(20 \%)$} & \\
\hline & male & female & & & \\
\hline & 6 & 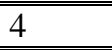 & & & \\
\hline & \multicolumn{2}{|l|}{$19-24$} & \multirow{3}{*}{2} & \multirow{3}{*}{$(4 \%)$} & \\
\hline & male & female & & & \\
\hline & 1 & 1 & & & \\
\hline & \multicolumn{2}{|l|}{ Total } & 50 & $100 \%$ & \\
\hline \multirow[t]{3}{*}{ Residence } & \multicolumn{2}{|l|}{ Inside Jalawla } & 40 & $(80 \%)$ & \multirow[t]{2}{*}{0.000} \\
\hline & \multicolumn{2}{|l|}{ Outside Jalawla } & 10 & $(20 \%)$ & \\
\hline & \multicolumn{2}{|l|}{$\begin{array}{l}\text { Total } \\
\end{array}$} & 50 & $100 \%$ & \\
\hline \multirow[t]{5}{*}{ Mothers education } & Illiterate & & 26 & $(52 \%)$ & 0.000 \\
\hline & Primary School & & 15 & $(30 \%)$ & \\
\hline & Intermediate School & & 6 & $(12 \%)$ & \\
\hline & High School & & 3 & $(6 \%)$ & \\
\hline & Total & & 50 & $100 \%$ & \\
\hline Crowding index & $1-3$ & & 15 & $(30 \%)$ & 0.000 \\
\hline & $\geq 3-5$ & & 30 & $(60 \%)$ & \\
\hline & $>5$ & & 5 & $(10 \%)$ & \\
\hline & Total & & 50 & $100 \%$ & \\
\hline Types of feeding & Exclusive breast feeding & & 4 & $(8 \%)$ & 0.000 \\
\hline & Partially breast feeding & & 4 & $(8 \%)$ & \\
\hline & Breast fed + complementa & y foods & 8 & $(16 \%)$ & \\
\hline & Exclusive bottle feeding & & 23 & $(46 \%)$ & \\
\hline & Bottle fed + complementa & y foods & 7 & $(14 \%)$ & \\
\hline & Solid diet & & 4 & $(8 \%)$ & \\
\hline & Total & & 50 & $100 \%$ & \\
\hline Socioeconomic & Poor & & 25 & $(50 \%)$ & 0.000 \\
\hline status & Medium & & 22 & $(44 \%)$ & \\
\hline & Good & & 3 & $(6 \%)$ & \\
\hline & Total & & 50 & $100 \%$ & \\
\hline
\end{tabular}


Table (2): The characteristics of weight, Height, and Head circumference of children with FTT

\begin{tabular}{|c|c|c|c|c|}
\hline \multicolumn{2}{|c|}{ Standard Deviation below the mean } & \multirow{2}{*}{$\begin{array}{c}\text { No. of infants } \\
2\end{array}$} & \multirow{2}{*}{$\begin{array}{c}\begin{array}{c}\text { Percent } \\
\%\end{array} \\
4 \%\end{array}$} & \multirow{2}{*}{$\begin{array}{l}\text { P Value } \\
0.000\end{array}$} \\
\hline Weight /age & $-2 \mathrm{SD}$ & & & \\
\hline & $<-(2-3)$ SD & 26 & $52 \%$ & \\
\hline & $<-3$ SD & 22 & $44 \%$ & \\
\hline & Total & 50 & $100 \%$ & \\
\hline \multirow[t]{4}{*}{ Height /age } & $-2 \mathrm{SD}$ & 8 & $16 \%$ & \multirow[t]{4}{*}{0.000} \\
\hline & $<-(2-3) S D$ & 30 & $60 \%$ & \\
\hline & $<-3 \mathrm{SD}$ & 12 & $24 \%$ & \\
\hline & Total & 50 & $100 \%$ & \\
\hline \multirow[t]{4}{*}{ Head circumference(OFC) /age } & Normal OFC & 16 & $32 \%$ & \multirow[t]{4}{*}{0.000} \\
\hline & $>+2$ SD & 2 & $4 \%$ & \\
\hline & $<-(2-3) \mathrm{SD}$ & 25 & $50 \%$ & \\
\hline & $<-3 \mathrm{SD}$ & 7 & $14 \%$ & \\
\hline
\end{tabular}

Table (3): The underlying causes of failure to thrive.

\begin{tabular}{|c|c|c|}
\hline Causes & No. of patient & P value \\
\hline A. Defective intake ( under nutrition ) & $20(40 \%)$ & \multirow{2}{*}{0.157} \\
\hline B. Organic causes & $30(60 \%)$ & \\
\hline 1. GIT & $11(22 \%)$ & \\
\hline Cow's milk intolerance & $3(6 \%)$ & \\
\hline Lactose untolerance & $2(4 \%)$ & \\
\hline Pyloric stenosis & $2(4 \%)$ & \\
\hline Cholestatic jaundice & $2(4 \%)$ & \\
\hline Cleft lip and palate & $1(2 \%)$ & \\
\hline Celiac disease & $1(2 \%)$ & \\
\hline 2. cardiovascular system & $4(8 \%)$ & \\
\hline \multicolumn{2}{|l|}{ VSD and heart failure } & \\
\hline 3. Renal system & $7(14 \%)$ & \\
\hline Urinary tract infection & $5(10 \%)$ & \\
\hline Post urethral valve & $2(4 \%)$ & \\
\hline 4. Nervous system & $2(4 \%)$ & \\
\hline \multicolumn{2}{|l|}{ Cerebral Palsy and mental retardation } & \\
\hline 5. Endocrine system & $1(2 \%)$ & \\
\hline \multicolumn{2}{|l|}{ Hypothyroidism } & \\
\hline 6. Metabolic : & $3(6 \%)$ & \\
\hline Galactosemia & $2(4 \%)$ & \\
\hline Gaucher's disease & $1(2 \%)$ & \\
\hline 7. Infections : & $2(4 \%)$ & \\
\hline \multicolumn{2}{|l|}{ Immune deficiency (congenital) } & \\
\hline Total & $50(100 \%)$ & \\
\hline
\end{tabular}




\section{Discussion}

Failure to thrive is a relatively common in our locality in this study, male gender was more predominant than female, although statistically insignificant, which was in agreement with other studies[3,6,25,30] but different from study done in Denmark where females were more commonly affected than males [20] ,since male gender is a risk factor for many diseases as well as due to different sampling technique. Thirty-eight patients $(76 \%)$ were under one year of age which is relatively high. This is similar to other studies [20,22,28,29]. This may be due to

rapid rates of growth-in infants, accompanied by marked developmental changes in organ function and composition, failure to provide adequate nutrient during this time due to low socioeconomic level where they lived ,is likely to have a diverse effect on development as well as growth as seen in other studies $[14,15,20,23,31]$. The main parameters in assessing growth in children are measurement of weight, height and head circumference. The criteria for classifying severe malnutrition as "edematous", "severely wasted" or" severely stunted" was applied [14,15,23]. In analysis of our patients with severe malnutrition, $44 \%$ their weight for age were <-3SD below the mean and this indicate severe malnutrition, 12 patients (24\%) their height for age were less than <3SD below the mean and this indicate severe stunting. Stunt growth usually considered having milder, chronic form of malnutrition, and their condition can rapidly worsen especially with the onset of complications such as diarrhea, respiratory infection or measles. Forty children (80\%) were from Jalawla town, this high number in the study may be related to most attended children to the hospital basically have FTT ,in addition to other health problems .The low percentage of children admitted from outside Jalawla, probably due to insecure general circumstances in the town as well as difficulties of transportations. Maternal education plays important role in rearing children. In our study illiteracy was found in $52 \%$ which is less than that found by other studies. [15,19,26,28] since their studies were done on urban slums and probably their socioeconomic level differs from our population. The socio economic status, of most patients were poor. Which indicates the burden of this factor on nutritional status of children, because of inadequate food intake as well as poor quality of foods offered to children. Most of studied children lived in overcrowded environment with crowding index $>3-5$ and this crowding index; reflect the low socio-economic status and increases the risk of recurrent infections .This is similar to what was found by Kashi et al. Twenty three children (46\%) were exclusively bottlefeeding which is dissimilar to other studies [5,11]. This may be related to difficulty establishing breast-feeding due to emotional stresses and general status of community, which increases the chance of practicing bottle-feeding and increases the incidence of repeated gastroenteritis and other infectious 
diseases. This will lead to FTT and malnutrition . Eighty-four percent of studied children were anemic; with $8 \%$ has $\mathrm{Hb}$ level of $<6 \mathrm{gm} / \mathrm{d}$ and blood film, were predominantly hypo chromic microcytic anemia, which is highly suggestive of iron deficiency anemia (IDA). This might be attributed to nutritional deficiency of iron, protein and other elements in the diet as well as biologically available iron and protein are present in animal sources of foods which are relatively expensive for the families to afford it to the child since most studied children come from low socioeconomic families. IDA during infancy has been associated with anorexia, irritability and lack of interest in their environment [2, 4.6, 8, 14] Fortunately all patients studied, have total serum protein and serum albumin in the normal range. Twenty patients $(40 \%)$ had nonorganic causes of failure to thrive, while $60 \%$, have organic causes of different systemic diseases particularly GIT, and renal diseases which is relatively higher than Olsen et al. study [20] who found, $46 \%$ of patients had organic causes of FTT. Although the nonorganic causes were most common, there may be overlap between organic and non-organic failure to thrive, owing to presence of minor infections, vomiting, and diarrhea together with behavioral problem. Therefore, some authors suggest the need for a third category "mixed" etiology.

\section{Conclusions}

Undernutrition is common in our locality with male preponderance, which is mainly due to poor socioeconomic status and maternal illiteracy.

\section{Recommendations}

From this study, we recommend the followings:

1-Improve the educational level of the mothers.

2-Encourage exclusive breast feeding particularly first 6 months of life .

3-Since IDA was common in our studied children we recommend routine iron supplement to all children below one year of age.

\section{References}

[1]Huh SY, Duggan CP. : A 19-Month-Old Girl with Failure to Thrive. N Engl J Med. 2018 , 15;378 (7):685-6.

[2]Perrin E, Frank D, Cole C, Deborah A., Stephan R., Nicholas Guerina, et al. Criteria for Determining Disability in Infants and Children: Failure to Thrive. Evidence Report/ Technology Assessment No. 72. AHRQ Publication NO. 03-E026. Agency for Healthcare Research and Quality, Rockville, MD, March 2003.

[3] Corbett SS, Drewett RF: To what extent is failure to thrive in infancy associated with poorer cognitive development? A review and meta-analysis. J Child Psychol Psychiatry. $2004 ; 45(3): 641-54$.

[4]Goh $\mathrm{LH}$, How $\mathrm{CH}, \mathrm{Ng} \mathrm{KH}$ : Failure to thrive in babies and toddlers. Singapore Med J. 2016 Jun;57(6):287-91. doi: 10.1162.

[5]Olsen EM, Petersen J, Skovgaard AM. B Weile, T Jørgensen, and C M Wright :Failure to thrive: the prevalence and concurrence of 
anthropometric criteria in a general infant population. Arch Dis Child 2007; 92:109.

[6]Spencer NJ. : Failure to think about failure to thrive. Arch Dis Child 2007; 92:95.

[7]Hughes I.. : Confusing terminology attempts to define the undefinable. Arch Dis Child 2007; 92:97.

[8]Casey PH. Failure to thrive. In: Developmental-Behavioral Pediatrics, 4th ed, Carey WB, Crocker AC, Coleman WL, et al (Eds), Saunders Elsevier, Philadelphia 2009. p.583.

[9] A Emond, R Drewett , P Blair, P Emmett: Postnatal factors associated with failure to thrive in term infants in the Avon Longitudinal Study of Parents and Children, Arch Dis Child 2007;92:115119..2005.091496. doi: 10.1136/adc.

[10]Larson-Nath C, Biank VF.: Clinical Review of Failure to Thrive in Pediatric Patients; Pediatr Ann. 2016 ;45(2): 46-9. doi: 10.3928/00904481.

[11] Dean E. : Faltering growth. Nurs Child Young People. 2017 , 12;29(5):11. doi: 10.7748 .

[12]Frank D. Failure to thrive. In: The Zuckerman Parker Handbook of Developmental and Behavioral Pediatrics for Primary Care, 3rd ed, Augustyn M, Zuckerman B, Caronna EB (Eds), Lippincott Williams \& Wilkins, Philadelphia 2011. p.204.

[13] Bergman P, Graham J. : An approach to "failure to thrive; Aust Fam Physician. 2005 ;34(9):725-9.

[14]Wright CM: Identification and management of failure to thrive: a community perspective. Arch Dis Child. $2000, ; 82(1): 5-9$.

[15] Lay Hoon Goh, Choon How How, ,Kar Hui $\mathrm{Ng}$, : Failure to thrive in babies and toddlers; Singapore Med J. 2016 Jun; 57(6): 287-291. doi: 10.11622/smedj.2016102.

[16]Scott D.Krugman, Howard Dubowitz:Failure to Thrive; Am F Physician. 2003 Sep 1;68(5):879-884.

[17] Dobowitz H, Black M. Failure to thrive. BMJ Best Practice. [Online] [Accessed March 25, 2018]. Available at: http://bestpractice.bmj.com/best practice/monograph/747.html .

[18] National Institute for Health and Care Excellence. Faltering growth: Recognition and management of faltering growth in children. NICE guideline (NG75). September 2017. Available at: https://www.nice.org.uk/guidance/ng75

(Accessed on July 22, 2018). [19]McDougall P , Drewett RF, Hungin AP, Wright CM.; The detection of early weight faltering at the 6-8-week check and its association with family factors, feeding and behavioural development.: Arch Dis Child. 2009 Jul;94(7):549-52. doi: 10.1136/adc.2008.139063.

[20]Olsen EM , Johannsen TH, Moltesen B, Skovgaard AM 2002, Failure to thrive among hospitalized 0-2 year-old children, Ugeskr Laeger. 2002 Nov 25;164(48):56548.

[21]Kachi Y, Fujiwara T, Yamaoka Y, Kato T (2018) , Parental Socioeconomic Status and Weight Faltering in Infants in Japan, 
Front Pediatr. 2018 May 1;6:127. doi: 10.3389/ped.2018.00127.

[22]Mash C, Frazier T, Nowacki A, et al. Development of a risk-stratification tool for medical child abuse in failure to thrive. Pediatrics 2011; 128:e1467.

[23]Cardona Cano S, Hoek HW, BryantWaugh R. Picky eating: the current state of research. Curr Opin Psychiatry 2015; 28:448. [24] Levy Y, Levy A, Zangen T, Kornfeld L, Dalal I, Samuel E, et al. :Diagnostic clues for identification of nonorganic vs organic causes of food refusal and poor feeding. $\mathbf{J}$ Pediatr Gastroenterol Nutr, 2009; 48:355. [25]Alvares M, Kao L, Mittal V, Misdiagnosed food allergy resulting in severe malnutrition in an infant. Pediatrics 2013; 132:e229.

[26]Kirkland RT, Motil KJ, Duryea TK. Failure to thrive (undernutrition) in children younger than two years: Etiology and evaluation [online] [Accessed May 23 2018]. Available at: http://www.uptodate.com/contents/failure-tothrive-undernutrition-in-children-youngerthan-two-years-etiology-and-evaluation . [27]Hager ER, Quigg AM, Black MM, : Development and validity of a 2-item screen to identify families at risk for food insecurity. Pediatrics 2010; 126:e26.

[28]Homan GJ: Failure to Thrive: A Practical Guide: Am Fam Physician. 2016 Aug 15;94(4):295-9.

[29]Baer TE, Scherer EA, Fleegler EW, Hassan A. Food Insecurity and the Burden of Health-Related Social Problems in an Urban
Youth Population. J Adolesc Health 2015; 57:601.

[30]Lay Hoon Goh, Choon How How, Kar Hui Ng: Failure to thrive in babies and toddlers, Singapore Med J. 2016 Jun; 57(6): 287-291.doi: 10.11622/ smedj.2016102.

[31]Wright CM, Williams AF, Elliman D, Bedford H, Birks E, Butler G, et al. :Using the new UK-WHO growth charts. BMJ 2010; 340:c1140. 